\title{
Indonesian Theatre Ten Years after Reformasi
}

\author{
Barbara Hatley \\ University of Tasmania
}

\begin{abstract}
Theatre contributed actively to the Reformasi movement of 1998 in Indonesia, as shows were staged that united students, NGO workers, artists and others in shared criticism of the Suharto regime and aspirations for change. Modern Indonesianlanguage theatre has a long history of political involvement. Developed among students in the Dutch colonial school system, its aim was helping create the Indonesian nation. This led to friction with other political groups and with state authorities. During the New Order regime, performances conveyed criticism that could not be expressed through other channels. In the post-Suharto era, however, when political criticism can be freely expressed and there is no united opposition movement to work with, theatre necessarily connects in a different way to its social context. In Central Java, where the writer's research has been based, contemporary theatrical performances are characterised by a shared focus on local identity and community. 'Local' culture is sometimes interpreted as the indigenous cultural forms of an area, but more often as the mixed local-global culture that residents practise today. The term 'community' is used to refer to immediate neighbours and to people with shared interests and experiences, who both watch and actively perform in plays. Such developments in theatre are clearly shaped by the heightened awareness of local identity fostered by regional autonomy and by the ideology of participatory democracy. But how do theatrical activities connect to other social forces and with the structures of the regional autonomy system? Is there any sense of future direction in the current vibrant celebration of local identity? In what ways does theatre in other regions reflect local social conditions? These important questions remain to be explored.
\end{abstract}




\section{Performing Reformasi}

In April 1998, I was lucky enough to be in Indonesia, to experience the excited anticipation of Reformasi, political reform, as the discredited New Order regime entered its final days and to witness some of the highly-charged theatre performances taking place in this context. The month of April was marked by art events throughout the country, referred to as ruwatan bumi [earth exorcism], and organised by artists and NGO activists. Here environmental, economic and political concerns were fused with traditional, healing rituals directed towards a ravaged, defiled Indonesia. Many performances staged in this context conveyed a sense of protest at as well as lamentation for the state of the nation. ${ }^{1}$ Sometimes the political message was overt and blatant, as in the case of a show at the Lembaga Indonesia Prancis, the Indonesian-French Cultural Institute, in Yogyakarta, which involved a skit by the popular theatre group, Dagelan Mataram Baru, and a short-story reading and monologue by actor Butet Kertarejasa. Elsewhere I have described the way the skit Monopoli satirised state economic mismanagement and military brutality by depicting a floundering business firm with an overbearing manager and comically protesting employees. Repeated appearances of a student demonstrator chased by a club-wielding thug related strongly to the daily confrontations taking place between student demonstrators and soldiers on the Gadjah Mada University campus a short distance from the theatre. Then Butet, wearing the familiar pici [fez cap], which President Suharto assumed for formal occasions, and mimicking Suharto's low, gravelly tones, wheezing laugh and characteristic speech errors, gave an hilarious, parody of a presidential speech. He advocated nurturing the world by cutting its unruly 'hair', removing its forests, and spoke of allowing only those he trusted most fully, his own family, to develop its resources. The huge crowd, predominantly students, along with NGO workers, artists and journalists, laughed uproariously throughout and delightedly mobbed the performers at the end, before spilling out euphorically into the night (Hatley 1999: 273-8; 2008: 184-7).

1 Marshall Clark (1999: 39-40) in describing the ruwatan bumi, mentions a play fragment depicting conflict between a soldier, a civil servant and a villager when their food supply runs out, and the sight of unemployed actors reciting poetry critical of the government while busking for money to survive. 
The composition of the crowd and the content and organisation of this event illustrated a commonality of outlook and processes of collaboration between performers and activists that had been strengthening over the preceding months. As the political crisis deepened in late April and May, the involvement of theatre in political action demanding Reformasi became still more direct. Student actors staged violent, comic skits in the midst of street demonstrations and Butet impersonated Suharto before the thousands of students occupying the parliament in Jakarta. Butet was in Yogyakarta, too, for the biggest Reformasi show of all in that city on 20 May, the day before Suharto's resignation. On that day, one million people walked to the city from all directions to gather in the main square to hear a message from the Sultan. Butet, playing Suharto, acted as master of ceremonies for the event, introducing various performers and entertaining the crowd until the Sultan himself appeared, calling on the populace to support the reform movement and on the armed forces to protect citizens as they did so.

Performance artists also participated actively in the celebration of Suharto's fall and the accompanying change by reading poetry and playing rock music on an open stage set up in the grounds of the Taman Ismail Marzuki cultural centre in Jakarta, and by staging wayang performances giving thanks for the resignation of unpopular officials in regional cities. ${ }^{2}$ There were numerous performances in the second half of 1998 and in 1999 depicting the political and communal violence that accompanied the ending of the Suharto regime - the murders and rapes of Chinese citizens, the inter-ethnic, inter-religious attacks - and suggesting that Reformasi had yet to bring about significant change, given the continuing power of New Order forces. ${ }^{3}$

2 A famous example occurred in the city of Tegal where the resignation of the unpopular mayor was marked by a performance by the zany puppeteer Enthus, attracting an audience of 70,000 people and blocking nearby roads (Lucas 2000).

3 Productions by Putu Wijaya's Teater Mandiri and Dindon's Teater Kubur played out graphic, wordless scenes of violent conflict; Kata Kita Mati by the Bandung company Payung Hitam and the monologue Lidah Masih Pingsan by Butet Kertarejasa focussed on the impossibility of real political change as Suharto's legacy was maintained (Hatley 1999: 279-82). 


\section{Indonesian Theatre and Political Resistance}

Such political involvement was nothing new for theatre in Indonesia. Modern, Indonesian-language theatre in particular has long history of political engagement and of confrontation with the state. Emerging in the early $20^{\text {th }}$ century among students from the Dutch colonial school system, within a general movement of political and cultural awakening, modern theatre took on the mission of helping to create the Indonesian nation-tobe. This inbuilt socio-political concern has, not surprisingly, led to conflict with other views and to frequent friction with state authorities. Michael Bodden puts the origins of antagonism between national art theatre and the state in a division between progressive and traditionally-minded members of the pre-war intellectual elite, which developed, through various historical transformations, the gap between liberal artists and authoritarian bureaucrats in the New Order period. Although marked by the inevitable complexities of cultural hegemony, a shared commitment to human rights and individual freedom characterises modern theatre and its practitioners, as opposed to the emphasis, among government representatives, on social stability and the glorification of conservative cultural 'tradition' (Bodden 2007: 66-87). And as state power holders used images from traditional regional cultures to support their hierarchical social control, theatre groups reinterpreted traditional narratives and theatre conventions to challenge the authority of officials and their policies. Some engaged the traditions seriously, some mocked and satirised kingly figures as the predecessors of contemporary leaders, others drew on the simple, participatory style of rural folk theatre to focus on village figures representing 'the people' (Hatley 1993). Another approach, pioneered by several Jakarta and Bandung theatre companies, was the production plays with minimal dialogue that used the physical movements of the actors' bodies to convey commentary on the violence and alienation of late New Order society. Such theatre, because of its abstract nature, was largely able to avoid being censored by state authorities. Censorship was a major concern for modern theatre, sometimes resulting in dramatic bannings such as those imposed on Rendra's Bengkel Theatre in the 1970s and Teater Koma in the 1990s. Yet in one sense these bannings, by attracting increased public attention, further highlighted and strengthened theatre's role in conveying critical opinions that could not be voiced through other channels due to the repressive control of the New Order regime. 
The simple, rustic style of theatre, known as sampakan and used by theatre groups to represent interaction among ordinary people, was adopted in the early 1980s by NGO organisations for community development and consciousness raising. For five to ten years, the teater rakyat [people's theatre] movement used theatre to build grass roots understanding of socio-political problems and to stimulate efforts to address them. Then these activities faded, perhaps because of a lack of power among theatre workers and NGOs to bring about the required social changes. But politically-oriented engagement between modern theatre and regional, popular performances continued. In 1991, several modern theatre figures worked with a director of ketoprak, Javanese-language popular melodrama, to produce ketoprak plesedan, a zany form of ketoprak, which subverted established political meanings through its absurd humour and attracted a huge popular following. The plesedan phenomenon, although responding to a new policy of political openness [keterbukaan] that had been recently announced by government leaders and performed widely live and on television, was called to a halt after a year, after several incidents with the authorities (Hatley 2008: 162-5). But other major political developments stimulated more critical performances-events such as the so-called Petrus killings of 1983, the Kedung Ombo dam issue, the July 1996 attacks on the offices of the PDI party and the death of the journalist Udin. As the opposition to Suharto strengthened, theatre practitioners collaborated more closely with activist groups, as we have seen, and audience numbers at their performances thrived.

\section{The Situation Ten Years On}

Ten years after the tumultuous ending of the Suharto regime, many questions surround the nature of the political order that has replaced it. The substantive democracy that the Reformasi movement strove for is still to be fully achieved; the regional autonomy system is often said to have enriched exploitative local elites and increased opportunities for corruption rather than empowering ordinary people. However these issues are judged, political conditions have clearly changed vastly: the context in which theatrical performances take place has been transformed. There is no single, authoritarian state to confront, no allpowerful leader to demonise and satirise. Similarly there is no broad- 
based opposition movement to work with and no mobilised body of students, NGO workers or other young people like those who flocked to critical theatre performances in the past. And in the new climate of freedom of expression, political commentary and criticism can be stated publicly and conveyed through the press and electronic media. There is no longer a sense of shock and dramatic urgency in hearing views proclaimed from the stage.

In the early months and years after the transition from the New Order, many people involved with the theatre expressed a sense of depression and confusion in coming to terms with these new social and political conditions. ${ }^{4}$ Observers of the theatre scene wrote of the 'confusion' and 'floundering, directionless' quality of contemporary performances (Bain 2000). Performers of regional-language, popular theatre forms, such as ketoprak, whose livelihoods depended on attracting sponsors and audiences, reported gloomily that the combination of economic crisis and fear of communal unrest had produced a dramatic decline in invitations to perform at private and community celebrations. Business sponsorship had almost dried up. For these actors, the loss of an audience base in the politicised student movement constituted a serious blow. Competition from the greatly expanded commercial television industry compounded their woes.

Yet, as I have reported elsewhere, on making visits in 2003 and 2004 to Central Java, the site of most of my theatre research, I found that theatrical activity was surprisingly lively and upbeat (Hatley 2008: 21946). In Yogyakarta there were big public performances and displays of local cultural forms in parades and carnivals, as well as numerous neighbourhood performances for Independence Day that were marked by an increased sense of social inclusiveness and popular participation. Chinese lion dancers, proselytising Muslim singers, bottom-wiggling dangdut girls and dreadlocked buskers playing ear-splitting heavy metal music - all these appeared on kampung stages and were warmly received by audiences and local officials. Officials themselves

4 Playwright and theatre director Riantiarno, head of the highly successful Jakarta company Teater Koma, and poet and playwright Afrizal Malna, both spoke in such terms in 1999 (Hatley 2008: 193-4). 
contributed actively, if sometimes diffidently and uncomfortably, to the show. In the field of modern 'art' theatre there were several fascinating if problematic reflections on Javanese identity, most notably Teater Garasi's Waktu Batu [Stone Time]; a multi-layered, avant-garde blending of archetypal myth and history with contemporary experience. What these performances indicated, I conjectured, was a heightened attention to local identity, which had been stimulated by the transition to regional autonomy, and an emphasis on inclusiveness and participation that reflected the ideology of participatory democracy.

Visits to Yogya and Solo in 2007 and 2008 revealed an even busier program of theatrical events. The 2008 Yogyakarta Arts Festival, held over two months rather than the usual one, made local art and performance a particular theme. There were performances by all kinds of local music groups, an artists' collective decorated the city walls with murals and a group comprising transvestite singers and sex workers staged a story about their lives. As the highlight of the festival, nine kampung groups created and performed plays enacting their own history. There were a number of other festivals during my two-week visit in early August: the Yogyakarta Asian Film Festival, the Kali Bedog environmental festival, a festival of experimental wayang puppetry, and traditional music, and an inter-district ketoprak competition, preceding the region-wide event later in the year. Many, many more festivals were planned.

In addition to the festival scene, numerous theatre groups were involved in activities with a local focus. The form and location of their shows and the composition of the casts varied greatly. Clearly shown here is an ongoing engagement with local identity. But what were the motivating forces for this concern? What features do such contemporary theatrical activities have in common and how do they differ? Can they be said to have a shared focus and aim, in the way that criticising and resisting the Suharto regime energised modern theatre during the New Order years and brought performers and activists together within the Reformasi movement? In what ways do recent theatre developments connect with their socio-political context and the work of other sectors of society? The following analysis attempts to address these questions by comparing a range of theatre activities. The examples are necessarily drawn from 
theatre in the Yogyakarta-Solo area, where my research is based and where I have seen these processes at work. How they compare with developments in other areas is a key question, to be posed at the end of the discussion.

\section{Picturing the Local Scene, Reporting on Theatre Activities}

Je.jal.an [Street throng] the 2008 production of the company, Teater Garasi, could be said to maintain the group's focus on contemporary Javanese identity. In contrast to the mythical, abstract space of the play Waktu Batu, however, Je.jal.an is set in the immediate, here-andnow environment of Indonesia's streets. Although not identified with any specific city, Je.jal.an's chaotic, sometimes violent, sometimes hilariously funny, interactions among the huge diversity of people in the street could well be taking place in Yogyakarta. The Muslim proselytiser and hip-hopping busker, whistle-blowing security guards, beggars, construction workers, dangdut singers and, sadly, also the terrorists swathed in Middle Eastern style headcloths; all could be locals. At the same time, the play's blending of 'confusion and creativity', in the words of director Yudi Tajuddin, symbolises the reality of contemporary Indonesia more broadly.

Alongside its own creative work, Teater Garasi provides a centre for documentation theatre activities, performances by other groups, workshops and discussions. In late 2006, it also commenced publication of $s k A n A$, an illustrated newsletter containing announcements, reviews and descriptions of theatrical events in Yogyakarta and its environs. Reported in skAnA are many efforts to extend theatre activities in the community: Garasi offering training courses for aspiring young actors, the group Gardanala staging story-telling in a busy shopping mall, Papermoon doing drama and music in schools and puppet theatre with children affected by the May 2006 Yogyakarta earthquake. Members of Anak Wayang Indonesia (AWI), a group formed in 1998, to foster theatre, dance and musical activities among young people in kampung communities, likewise performed their characteristic blend of songs, games and play skits 19 times in villages in Bantul, the worst hit area in the earthquake (Rini 2006: 12; Ba'syin 2006: 33-8). Local Bantul actors, 
particularly ketoprak groups, were also very active after the earthquake. By staging rudimentary performances and participatory workshops they could lift their own spirits (many were homeless themselves), and give something back to the communities that had provided them with a livelihood in the past by hiring them to perform. ${ }^{5}$

\section{Performing in and for Communities}

In Solo, several groups, including Teater Gidag-Gidig, Teater Ruang and Komunitas Wayang Suket, are committed to direct community outreach. Teater Gidag-Gidig, formed in 1978 when its leaders, Hanindawan and Bambang Sugiarto, were still in high school, has long performed avant-garde modern plays in cultural centres, and ketoprak shows on Independence Day for the residents of the kampung neighbourhood where the group rehearsed. In 1998, after the violent ethnic and classbased riots that took place just before Suharto resigned, Gidag-Gidig decided to stage their ketoprak shows more widely. At this time of inter-group tension and suspicion, performances to bring communities together in shared enjoyment and celebration were vitally important. Yet fear of communal disturbance often stopped people from organising such performances. Gidag-Gidig made arrangements to perform in several neighbourhoods where group members had personal connections and where it was felt their message of community harmony and solidarity was needed. Since then they have performed each Independence Day at numerous places in and around the city. Their style of performance is simple, playful and light-hearted, with actors sitting with the musicians, playing and singing, until it is their turn to appear on stage. Stories of kings and courts and village folk often portray noble leaders as ludicrously pompous and ordinary people more sympathetically, but the mood is one of cultural celebration rather than social criticism. Frequent references in the dialogue to local people and events spark frequent laughter and interjections from audience members and humorous responses from the actors. These interactions create a sense of shared enjoyment and engagement, celebrating community bonds. They also

5 In the words of ketoprak playwright Bondan Nusantara, 'Our wages had been paid by them...this was the time to repay their goodness' (personal communication, June 2006). 
show how vital and dynamic live performances can be compared with television and other media and convey an impression of contemporary Javanese-Indonesian culture as being lively, multi-layered and fun.

\section{Directly Involving 'the people'}

While the skilled actors of Gidag-Gidig stage their lively shows before kampung audiences, but Komunitas Wayang Suket and Teater Ruang involve community members themselves in performances. Both these groups have invited residents from the surrounding neighbourhoods to make use of their sanggar, their rehearsal studio and meeting space, for performance practice. In each case, the work of the artists group is innovative and experimental, while the local people employ more to traditional, conventional performance styles.

Slamet Gundono, leader of Komunitas Wayang Suket, is an internationally renowned experimental dalang [shadow puppeteer], who uses his characteristic grass puppets and more conventional wayang in combination with dance, song, film clips and music of all styles, to bring to life traditional wayang legends in contemporary contexts. ${ }^{6}$ In the production Kelingan Lamun Kelangan, [Remembering and Loss], for example, the story of Dewi Kunthi, who discards her son Karno in the river rather than suffer unbearable shame as an unwed mother, evokes comparisons with the ongoing sufferings of women and with contemporary inter-communal violence, as the adult Karno fights on the opposite side to his birth family in the Bharatayudha war. And in a new style of wayang invented by Gundono, wayang air [water wayang], dancers playing with water in buckets and plastic tubs reflect on water's role as the source of life and human creativity, but also on the difficulty many Indonesian households experience in getting clean water (Iskandar 2007).

Teater Ruang's plays, written and directed by the group's leader, Joko Bibit Santoso, are intensely physically demanding, using actors' bodies

6 The name of the group, Wayang Suket, refers to these puppets (suket means grass in Javanese), which are styled after the grass puppets traditionally made by village children in imitation of standard leather wayang puppets. They convey suggestions of simple, rural life and populist, communal values. 
as well as everyday objects in surprising, imaginative ways. A torch, lighting up the bare torsos and faces of the two actors, is central to the staging of the play, Z, about a male homosexual relationship. Ablencong, the oil lamp used in wayang kulit performances, is the only source of light in stagings of Plencong. The blencong creates wild wavering shapes as actors walk on their hands and take up other extreme postures, representing dimensions of psycho-spiritual experience. In a recent performance of Jaga Malam [Night Guards], torches are again used by three men doing guard duty in and around a tree. But in this example of what Joko Bibit terms budaya gerilya [guerilla culture], staged in village and kampung communities to subvert the hold of television and other mass media, the object central to the show is unseen. It takes the form of a television set, located in the stomach of a pregnant woman who begs the guards for help — she has been raped by the media, and this is the terrifying, menacing result.

Rather than experimenting with new forms, the neighbourhood group connected to Komunitas Wayang Suket builds on the skills of its members in traditional Javanese arts. Yet on one occasion at least they performed in a startlingly unconventional location. In early 2007, a large group of kampung actors and their friends staged a wayang dance-drama and an exuberant harvest festival in a glamorous, multi-storey shopping mall in the centre of Solo. Television footage of the event shows crowds of shoppers watching in delight as the actors exchange comic dialogue and Slamet Gundono narrates, then everyone dances and huge piles of grass are thrown in the air. The purpose of the event, Gundono explained, was to embolden kampung people to enter the intimidating hyper-modern spaces of their city, to confront the elitist attitudes that often discourage them from doing so, and to give urban middle class people a taste of the vitality, humour and fun of lower class, kampung and village culture. Another related concern espoused by Gundono is sustaining and revitalising specific Javanese cultural forms-gathering farmers groups at his sanggar to stage a traditional pacul gowang disaster-resisting ritual, as they confront contemporary land problems, or holding a festival of dongeng story-telling to encourage kampung parents to tell stories to their children as happened in the past. 
Teater Warung Surakarta is named in reference to the food-stall, warung, near Teater Ruang's sanggar where kampung residents often congregate. Comprised of local people, the group stages Javanese-language plays written by Jaka Bibit depicting interactions among ordinary working people like the actors themselves. In Lurung Kalabendu [Street of Disasters] these figures include a bent, grey-haired old woman tending a tiny street stall, a becak driver, a quarrelling husband and wife and an old man dispensing Javanese wisdom. Many of their conversations are abrupt, aggressive, full of complaints and abuse about everyday troubles. A self-styled prophet-madman riding a hobby horse made from a mop, laments the decline of Javanese people today into quarrelling and conflict, and repeats that only unity will bring strength, santosa. Such words fail to convince the furious drunken husband who, vowing to kill his wife, stumbles in front of a truck and is killed. Everyday small disasters have escalated into a major one. The group has performed the play several times in their own community and in other kampungs and villages, even as far afield as the Bagong Kussudiardjo cultural complex in Yogyakakarta.

\section{Comparing Styles and Aims}

Clearly a focus on the local and on the community is crucially important in all the theatrical activities described above, although the way these terms are interpreted and applied varies from group to group and in particular circumstances.

For Slamet Gundono, sustaining and reviving local theatre genres in their original form and invoking their past social roles motivates his organising of festivals of traditional performance. Concerned at the loss of cultural diversity and social solidarity resulting from modernisation and globalisation, he re-presents local, indigenous performances and suggests ways in which their past social functions could be applied in today's conditions. Direct involvement of community members in these activities is vital. Similarly, Gundono encourages members of the local community around his sanggar to draw on their existing skills in wayang performance and train new performers, as a basis of cultural 
confidence in facing the sophisticated urban elite. His own performances, meanwhile, are marked by a free mixing of genres from various local Javanese regions with modern, international cultural styles, references and technologies. Java-Indonesia takes on the world.

In most cases, however, the understanding of 'local' is more flexible and eclectic. Teater Gidag-Gidig styles its performances kethoprak pendhapan, in reference to the type of ketoprak once staged in the pavilions, pendopo, of village houses, and employs conventional ketoprak elements such as court audiences and tembang love songs. But the constant joking, informal language and incorporation of contemporary references is emphatically here-and-now. Other groups use contemporary modern theatre, international forms such as puppetry and Western-style pop music, even hip-hop and rap. Rather than attempting to engage with the indigenous cultural forms of a specific area, they work with performance styles that people living in that area recognise and practise today. Yet, it is interesting that the language used in dialogue and song is predominantly and increasingly Javanese.

The term 'community' is used to refer to a physical neighbourhood and to people with shared interests and experiences like the transvestite sex workers and singers who performed in the Yogyakarta Arts Festival and collectives of mural painters or street singers. Most of the examples involve community in the first sense: people living close together in kampungs and villages. Theatre groups may engage local people as audiences-Anak Wayang Indonesia members performing to cheer the spirits of other young people in earthquake devastated areas, for example. More often community members themselves perform. In each case the performance is consciously 'constructed', not an ongoing, traditional cultural activity. Some groups use techniques reminiscent of the teater rakyat movement of the 1980s, simple folksy performance styles and scenarios with local social reference. But rather than political mobilisation, the aim is to strengthen a sense of communities-to reinforce the social bonds among local people, and encourage their enjoyment of and pride in their own culture. There is an assumption that local social solidarity and cultural richness has been weakened or lost through social change, but community theatre can help restore it. 
Such activities seem clearly influenced by the focus on local identity promoted by regional autonomy. At the same time there is a sense that local cultural practices have been greatly attenuated by social and economic change. A particular, local understanding of the phenomenon of 'the accelerating "liquefaction" of modern life', in Zygmunt Bauman's terms (2000: 170) might be seen at work. The experience of the communal violence of 1998 in Solo, and of the devastating 2006 earthquake in Yogya, have further heightened the sense of the fragility of local society and culture but, arguably, also increased awareness of their importance. Theatre's perceived capacity to bring people together to celebrate their own culture gives it a special role in this context.

\section{Wider Socio-Political Connections}

How does such thinking and activity fit with contemporary political and social realities, with the structures of regional autonomy and the constant struggles for office and influence between competing political forces? While the elections for governors, bupatis, mayors and parliamentarians provide opportunities for well-known performers to appear as entertainers at campaign events and even as candidates (Lindsay 2005), community theatre groups make use of the current political system in other ways. Funding for local festivals can be obtained from the Department of Tourism and from regional officials, who often mobilise private business sponsorship (Lindsay 2008). ${ }^{7}$ Organisations of performers of regional theatre forms, particularly ketoprak in the Special Region of Yogyakarta, have been successful in obtaining substantial funding from district budgets for their programs of competitions, workshops and activities in schools (Hatley 2008: 198, 287). At the same time such arrangements are highly contingent, reliant on the goodwill of particular officials and the negotiating skills and connections of artists.

A revealing example of collaboration between theatre practitioners,

7 A well-known Yogya performer confided that one of his motivations in organising a recent environmental arts festival was that it was possible to get funding for such events from local officials and other sponsors, but support for performance activities per se would not be forthcoming. 
local communities and wider political and administrative structures, directed specifically at theatre as an expression of community identity, occurred within the state-funded, 2008 Yogyakarta Arts Festival. In one program, titled Babad Kampung [kampung histories] nine kampung communities within the city of Yogyakarta, representing different patterns of settlement and development, were selected to stage performances playing out their local stories as festival events. The Sultan of Yogyakarta and governor of the Yogyakarta Special Region, Sri Sultan Hamengku Buwono X, was patron; the organising subcommittee, which provided guidance and assistance to the kampung theatre groups, comprised theatre practitioners and NGO activists. The Babad Kampung coordinator, Yoshi Fajar Kresno Murti, introducing the final performance of the series, said the aim of the program had been to bring people together to work collaboratively to produce new creativity at the level of the kampung. For kampung neighbourhoods are plural sites, comprising people of all kinds, old and young, male and female, of different racial, social and religious backgrounds, yet with common rights and responsibilities. The Sultan, in a speech on the same occasion, said that for him the most important aspect of the Babad Kampung project was to focus attention on traditions of community solidarity and support. These had become attenuated in recent years, as changes in local administrative structures and physical infrastructure had reduced communication between former neighbours. However, the experience of the 2006 earthquake had shown the continuing solidarity of Yogya communities. Patterns of mutual assistance and support were vital sources of social capital and societal strength.

The program was very successful, engaging large numbers of people as performers and attracting big, enthusiastic audiences; the shows varied in accordance with local performing skills and social relations. Of the two performances I saw, for instance, one took place in the kampung of Pajeksan, well-known as the home of many ketoprak performers. It was directed by a professional ketoprak director and included several current and former professional actors. With lavish costumes and scenic backdrops it played out a mythical ketoprak story about a competition for the hand of a daughter of an adipati, regional official, enlivened by such attractions as a rap rendition of the Kalatidha by Javanese 
court poet Ranggawarsita, and singing and dancing by the princess' handsome sweetheart, in real life the local camat [sub-district head] and leader of a pop music band. The camat played the part of a Chinese, at first rejected by the adipati because of his race, but eventually accepted as his daughter's husband; this was a reference to the large numbers of Chinese shopkeepers living on the edge of the kampung. In another local connection, the adipati appoints the hero's spiritual mentor, a huge, comic figure, as a jaksa [judge]. The name Pajeksan is said to derive from a famous jaksa who once lived there. The other performance, in the kampung of Minggiran, played on a simple, hastilyerected stage, was a story about contemporary kampung life, written by an amateur theatre and ketoprak performer, directed by a former busker, who still writes socially-critical songs for his busker friends, and acted by teenagers, most of them still at school. The play opens with children performing traditional Javanese children's songs, then a married couple talk about the husband's work at the palace, in reference to Minggiran's proximity to the Yogyakarta palace. The pair are having difficulty with their rebellious, disrespectful teenage son. In a later scene this young man confesses to friends that he has fallen in love; the girl in question reveals in turn to her astounded friends that she loves the anti-social rebel. The young man fears he will have great difficulty in getting agreement to their marriage from the girl's parents. His friends advise him how to become a helpful, respectful kampung citizen, thereby getting a good 'report card', and the girl. After this lesson in kampung neighbourliness, the performance ends with lively dangdut music, and audience members and actors join together in exuberant joged dancing.

The Pajeksan performance was much grander than the Minggiran show and involved more historical references and traditional elements. It also had strong support and direct participation from local officials, whereas in Minggiran relations between performers and officialdom had been more distant. ${ }^{8}$ Yet both performances were hugely enjoyable, local events. And both were beneficiaries of the largesse of the Sultan, who awarded a prize of 10 million rupiah to each community participating in

8 Local bureaucrats had at first reacted coolly to the invitation to participate in the Babad Kampung program but eventually warmed to the idea when they realised it had strong support from the Sultan (Eko Nuryono personal communication 2008) 
the Babad Kampung program, in recognition of their achievement and to encourage further activities.

Yoshi, the program co-ordinator, reported the complexities of the organising process. One was the wish of residents to tell only good news about their neighbourhood, avoiding mention of practices regarded as shameful and past events that have caused trauma, such as the 1965 anti-Communist massacres and the Petrus killings. In some kampungs local officials intervened to exclude mention of 'unseemly' themes such as superstitions about local sites but in others reference to supernatural events abounded. One kampung had been strongly leftist before 1965, with many ketoprak players and other traditional performers. Now these figures are long gone or inactive, and the predominant form of local performance is a kind of kroncong operetta, performed by young people who have no memory of the political traumas of the past. What these young people are aware of, however, is current political injustice and corruption. On the night of the performance they departed from the rehearsed format of the show to depict the corruption of contemporary local officials. The officials were shocked and offended and left the event early. The young people, however, were very proud of their show and have continued to hold rehearsals and plan future performances. In another Babad Kampung follow-up activity, the local committees of the nine participating communities meet monthly to discuss shared experiences and make plans that include how to use the prize money from the Sultan. Outside management is essential here, Yoshi believes, to coordinate and monitor expenditure. It would hardly be wise, for example, for each group to spend their money buying an electronic keyboard (Yoshi Fajar Kresno Murti, personal communication August 2008).

The Babad Kampung program is a particularly impressive example of the way theatre activists, local political leaders and community groups can work together in the contemporary climate. Whether or not political ambitions combined with communal ideals in motivating the Sultan's support, local people benefited greatly. ${ }^{9}$ Also highlighted are the varying

9 The Sultan was publicly considering contesting the 2009 Presidential election at the time of the performances and has since announced his candidature. In awarding the prizes he might arguably be seen as acting in 'campaign mode', seeking to impress voters with his generosity and closeness to ordinary people. 
roles of local officials and the comparative freedom of performances compared with New Order times. Evident, too, are complexities in the relations between theatre activists and community members: activists encouraging frank reflection on local history, but local people wishing to present a positive face to the world; activists encouraging community autonomy but not trusting local people to spend their prize money wisely. Although today's theatre activists seem to have turned from political struggles to focus on local identity, local people themselves may make use of stage performances to express political criticism and comment on class differences.

\section{Concluding Reflections}

Celebrating local identity and connecting with the community are the shared aims of the theatrical activities described above. Such a focus is clearly influenced by the social and ideological climate of regional autonomy. Yet the performances produced differ markedly from the slick, glamorised renditions of traditional music and dance used by local bureaucrats to promote the cultures of their regions. Here interpretations of 'local' are varied and eclectic, encompassing traditional forms and contemporary pop culture, often combining regionally specific elements with global influences. Although 'celebrating' local community might mean for Babad Kampung participants highlighting the positive, for the groups Garasi in Yogya and Teater Warung Surakarta in Solo it is to depict life in the streets and in kampung communities 'warts and all', with all their aggression and dysfunction. It is the energy and artistry, the pride and delight in the opportunity to perform that makes such shows 'celebratory'.

Theatre groups in the late New Order years had a common mission of political criticism and resistance, while today they share general values but work in diverse ways, with their own approaches. The fact that artists, NGO workers, students and others can still be mobilised into joint political action was illustrated in 2006 by arts events that were organised to protest against the proposed anti-pornography legislation. 
In recent months the re-introduction of the legislation to parliament has seen these forces re-group, staging lively protest gatherings. ${ }^{10}$ Meanwhile ongoing collaboration between actors, other performing artists and NGO activists takes place in the form of dispersed, pragmatic activities - organising festivals, staging exhibitions, providing spaces to perform. News of these events is circulated widely through e-mail networks, websites and other media. The intense volume of performance and the energy and enthusiasm involved is most impressive.

One might ask about the long-term goals of such activities. What kind of future do artists and activists envisage for local communities with their strengthened social bonds and sense of cultural identity? Might celebration of local culture be seen to some degree as a substitute for more direct political action, a distraction from practical social problems? Another question is the extent to which performance activities similar to those of Yogya and Solo are taking place in other regions of Indonesia. Clearly there are particular factors fostering the dynamism of the Yogya and Solo scene: the rich traditions of court performance in these cities; the presence of strong institutions of the arts and widespread creative activities; an emphasis on local community heightened by events such as the 1998 Solo riots and the 2006 Yogya earthquake; and the role of the Yogya Sultan. Theatre and the arts in other regions surely also reflect local conditions. In West Java, for example, festivals of Sundaneselanguage plays attract scores of entrants and great public attention in the context of a general revival of Sundanese-language and culture. In Surabaya, independent film-making is reportedly particularly vibrant, although what contextual influences are at work I do not know. ${ }^{11}$ All these activities are part of a huge work in progress, the emergence of post-New Order, post-Reformasi Indonesia. Whatever form the new

10 See for example, the all-day program of activities outside the Yogyakarta parliament building on 22 September 2008 organised by YUK, Yogyakarta Untuk Keberagaman, the Foundation for Diversity. The program included speeches by such famous figures as the wife of the Sultan and actor and monologist Butet Kertarejasa, and was enlivened by various performances and supported by over 100 social, religious, educational and arts organisations (Perempuan mailing list, perempuan@yahoogroups.com, accessed 21 September 2008).

11 My source of information about Sundanese-language theatre is the Bandung actor and director, Wawan Sofwan. Surabaya-based academic, Dr Rachmah Ida, has mentioned the thriving film scene in her city. 
Indonesia may take, local performance and arts activities will surely play an active part in the process. What capacity they may have to move beyond reflection into envisaging and leading change is another tantalising question.

\section{References}

\section{Books and Journals}

Bain, Lauren. 2000. 'Confused? Some Directions in Post-New Order Theatre'. Inside Indonesia. No. 64. October-December.

------. 2005. 'Performances of the Post-New Order'. Unpublished PhD thesis. School of Asian Languages and Studies: University of Tasmania.

Bauman, Zygmunt. 2000. Liquid Modernity. Oxford: Polity Press.

Bodden, Michael. 2007. "Tradition", "modernism" and the struggle for cultural hegemony in Indonesian national art theatre'. Indonesia and the Malay World. Vol. 35. No. 131. March: 63-92.

Clark, Marshall. 1999. 'Cleansing the Earth', in Edward Aspinall, Gerry van Klinken and Herb Feith (eds). The Last Days of President Suharto. Clayton, Victoria: Monash Asia Institute, Monash University, pp. 37-40.

Hatley, Barbara. 1993. "Constructions of "Tradition" in New Order Indonesian Theatre', in Virginia Matheson Hooker (ed.). Culture and Society in New Order Indonesia. Kuala Lumpur, Singapore, Oxford: Oxford University Press, pp. 48-69.

-1999. 'Cultural Expression and Social Transformation in Indonesia', in Arif Budiman, Barbara Hatley and Damien Kingsbury (eds). Reformasi: Crisis and Change in Indonesia. Clayton, Victoria: Monash Asia Institute, Monash University, pp. 267-286.

2008. Javanese Performances on an Indonesian Stage: Contesting Culture, Embracing Change. Singapore: Asian Studies Association of Australia in association with NUS Press.

Iskandar, GB. 2007. 'Wayang Air Ki Slamet Gundono'. skAnA 3. 9.

Lindsay, Jennifer. 2005. 'Performing in the 2005 Elections', in Margaret Kartomi (ed.). The Year of VotingFrequently: Politics and Artists in Indonesia's 2004 Elections. Clayton, Victoria: Monash Asia Institute, Monash University.

-------. 2008. 'A New Artistic Order?' Inside Indonesia. No. 93. August-Oct.

Lucas, Anton. 1999. 'The Mayor Who Fell Down the Well'. Inside Indonesia. No. 59. July-September: 11-12.

Muhamad, Anis Ba'asyin. 2006. 'Ngobrol Bareng Anak Wayang Indonesia'. skAnA 1:33-8.

Rini, Hindra Setya. 2006. 'Kukuh Baku'. skAnA 1: 8-14. 